\title{
Stringent Response Regulates Stress Resistance in Cyanobacterium Microcystis aeruginosa
}

\section{OPEN ACCESS}

Edited by:

Francesco Pomati,

Swiss Federal Institute of Aquatic Science and Technology, Switzerland

Reviewed by:

Leda Giannuzzi,

Consejo Nacional de Investigaciones

Científicas y Técnicas (CONICET),

Argentina

Brendan Paul Burns,

University of New South Wales,

Australia

*Correspondence:

Zhong Hua Cal

caizh@sz.tsinghua.edu.cn

${ }^{t}$ These authors have contributed equally to this work

Specialty section:

This article was submitted to

Aquatic Microbiology,

a section of the journal

Frontiers in Microbiology

Received: 13 November 2019

Accepted: 16 October 2020

Published: 12 November 2020

Citation:

Jin H, Lao YM, Ying KZ, Zhou J and Cai ZH (2020) Stringent

Response Regulates Stress

Resistance in Cyanobacterium

Microcystis aeruginosa.

Front. Microbiol. 11:511801.

doi: 10.3389/fmicb.2020.511801
Hui Jin ${ }^{1,2 \dagger}$, Yong Min Lao ${ }^{3+}$, Ke Zhen Ying ${ }^{1}$, Jin Zhou ${ }^{1}$ and Zhong Hua Cai ${ }^{1 *}$

${ }^{1}$ Shenzhen International Graduate School, Tsinghua University, Shenzhen, China, ${ }^{2}$ School of Pharmaceutical Sciences (Shenzhen), Sun Yat-sen University, Guangzhou, China, ${ }^{3}$ Institute for Advanced Study, Shenzhen University, Shenzhen, China

Cyanobacterial blooms are serious environmental issues in global freshwater ecosystems. Nitrogen limitation is one of the most important strategies to control cyanobacterial blooms. However, recent researches showed that $\mathrm{N}$ limitation does not effectively control the bloom; oppositely, $\mathrm{N}$ limitation induces $\mathrm{N}$-fixing cyanobacterial blooms. The mechanism underlying this ecological event is elusive. In this study, we found that $\mathrm{N}$ limitation enhances stress tolerance of Microcystis aeruginosa by triggering stringent response (SR), one of the most important bacterial adaptive responses to environmental stresses. Initiation of SR exerted protective effects on the cells against salt and oxidative stresses by promoting colony formation, maintaining membrane integrity, increasing photosynthetic performance, reducing ROS production, upregulating stressrelated genes, etc. These protections possibly help $M$. aeruginosa maintain their population number during seasonal $\mathrm{N}$ limitation. As SR has been proven to be involved in nitrogen fixing under $\mathrm{N}$ limitation conditions, the potential role of $\mathrm{SR}$ in driving the shift and succession of cyanobacterial blooms was discussed. Our findings provide cellular evidence and possible mechanisms that reducing $\mathrm{N}$ input is ineffective for bloom control.

Keywords: stringent response, stress tolerance, Microcystis aeruginosa, cyanobacterial blooms, guanosine $3^{\prime}, 5^{\prime}$ bisdiphosphate

\section{INTRODUCTION}

Cyanobacterial blooms are global environmental issues that threaten the freshwater ecosystem (Paerl et al., 2011). Cyanobacteria produce taste and toxic compounds and therefore endanger the safety of drinking water, poison zooplankton, and fish and even cause the death of humans through the food chain (Szlag et al., 2015). Large accumulation of cyanobacteria induces anoxia and causes the death of aquatic organisms (Paerl and Tucker, 1995). At the end of the bloom, dead cyanobacteria and fish floating on the surface contaminate water and destroy the landscape. Cyanobacterial blooms pose serious threats to public health and lead to a lot of undesirable economic, ecological, and resource problems (Havens, 2008). Despite decades of research and billions of dollars spent on it, the problem of cyanobacterial blooms persists and appears to have worsened in some regions.

To control cyanobacterial blooms, many possible causes have been studied and proposed. The emphasis has been heavily on curtailing the input of nutrients, including N, P, Fe, and Si (Paerl et al., 2011; Molot et al., 2014). In addition, temperature, salinity, light, and climate changes are also considered to be related to cyanobacterial blooms (Paerl et al., 2001; Yang et al., 2016). Although 
restriction of $\mathrm{P}$ input has been implemented widely since the 1960 s, the need to reduce $\mathrm{N}$ input for controlling cyanobacterial blooms was proposed in recent years (Conley et al., 2009; Paerl et al., 2011). However, recent studies showed that reducing $\mathrm{N}$ input flavored $\mathrm{N}$-fixing cyanobacteria and therefore could not effectively control cyanobacterial blooms (Schindler et al., 2008; Lewis, 2017; Higgins et al., 2018). The mechanism behind this ecological event is elusive. As early habitants on Earth, cyanobacteria acquired complex strategies to survive various environmental stresses during their long evolutionary history (Kulasooriya, 2011). For example, cyanobacteria that cannot fix nitrogen are able to survive prolonged periods of nitrogen starvation as chlorotic cells in a dormant state (Klotz et al., 2016). Dormant-like cyanobacterial cells can resist environmental stresses at a larger extent than normal vegetable cells. Therefore, we cannot gauge the true effect of $\mathrm{N}$ limitation on cyanobacterial blooms without thoroughly understanding the stress tolerance mechanisms underlying the ability of cyanobacteria to survive in prolonged $\mathrm{N}$ starvation. Given the observed increase in N-limited and N\&P co-limited freshwater systems worldwide (Elser et al., 2007; Moisander et al., 2009), we hypothesize that stress tolerance activated by $\mathrm{N}$ limitation could help non-N-fixing cyanobacterial cells survive more easily than other planktonic algae. But the stress tolerance mechanism activated by $\mathrm{N}$ limitation is unknown in many cyanobacteria.

To survive in $\mathrm{N}$ deprivation conditions, cyanobacteria have evolved several adaptative mechanisms. Stringent response (SR), a global regulatory system, is activated by $\mathrm{N}$ deprivation and leads to metabolic change from fast growth into survival maintenance (Masuda, 2012). SR is mediated by an effector molecule, guanosine $3^{\prime}, 5^{\prime}$-bisdiphosphate (ppGpp), which is derived from guanosine pentaphosphate (pppGpp) by hydrolysis. Collectively, pppGpp and ppGpp are termed (p)ppGpp (Braeken et al., 2006). A growing number of studies indicate that SR regulates many biological processes in bacteria, such as growth adaption (Potrykus et al., 2011), antibiotic production (Eymann et al., 2001; Inaoka and Ochi, 2002), morphological differentiation (Dahl et al., 2005), sporulation (Chakraburtty and Bibb, 1997; Hesketh et al., 2007), social behavior (Van Delden et al., 2001), and fruit body development (Harris et al., 1998). In Escherichia coli, two proteins are involved in SR: RelA and SpoT. RelA is associated with ribosomes and produces ppGpp in response to amino acid starvation (Wendrich et al., 2002). SpoT is a bifunctional enzyme which exhibits strong degradative and little synthetic activities; it regulates ppGpp level under most stresses (Gentry and Cashel, 1996; Magnusson et al., 2005).

SR plays an important role in defending abiotic stress, such as nutrient deprivation (Vinella et al., 2005; Rifat et al., 2009; Nguyen et al., 2011), temperature (Yang and Ishiguro, 2003), salt stress (Takahashi et al., 2004), and biotic stress including pathogen infection (van der Biezen et al., 2000). In most bacteria, SR lies at the top of the network to govern global gene expression in response to environmental stress. During stress response, SR not only stimulates expression of stress-induced genes but also activates transcription of genes that mediate general defenses (Traxler et al., 2011). General defense activated by SR confers cyanobacteria resistance to environmental stress. For instance, in E. coli, upon exposure to nutrient depletion, SR upregulated genes involved in RopS-dependent response, a general acclimation response, and carbon catabolism genes for cells to switch to alternative carbon source (Traxler et al., 2006, 2008, 2011). Also, SR enhanced tolerance to antibiotics by curtailing production of prooxidant metabolites in Pseudomonas aeruginosa (Nguyen et al., 2011).

Microcystis aeruginosa, one of the most common non-Nfixing cyanobacteria in bloom, has long been a primary focus. In the course of evolution, $M$. aeruginosa acquired sophisticated strategies to improve stress tolerance, for example, dormantlike cell formation for surviving prolonged period of nutrientlimited conditions (Zou et al., 2018), colony formation for protecting cells from stress (Yang et al., 2005), and buoyancy regulation for overcoming the vertical separation of light and nutrients in the water column (Thomas and Walsby, 1985). In this study, we endeavor to (1) identify the SR system, the key Marsh gene, in M. aeruginosa; (2) determine the tolerance ability of $M$. aeruginosa to environmental stress conferred by SR; (3) disclose possible mechanisms underlying the SRinduced stress tolerance; and (4) discuss the role of SR in cyanobacterial blooms.

\section{MATERIALS AND METHODS}

\section{Bacterial Strains and Growth Conditions}

$M$. aeruginosa NIES-843 strain was obtained from the Institute of Hydrobiology, Chinese Academy of Sciences. E. coli strains CF1648 and CF1693 were kindly donated by Michael Cashel (Gentry and Cashel, 1996). M. aeruginosa cells were cultivated in conical flasks containing $100 \mathrm{ml}$ of Blue-Green medium (BG-11) in an illumination incubator at $25^{\circ} \mathrm{C}$ for constant illumination $\left(20 \mu \mathrm{mol}\right.$ photons $\mathrm{m}^{-2} \mathrm{~s}^{-1}$ of cool white fluorescent lights) under a $12 \mathrm{~h}$ light/12 $\mathrm{h}$ dark cycle and shaken manually twice daily.

\section{Triggering SR in $M$. aeruginosa}

To trigger SR, M. aeruginosa cells were exposed to classic stresses, such as nitrogen depletion, hyperosmotic stress, oxidative stress, and serine hydroxamate (SHX), which is a classic inducer of SR. Then the transcription of Marsh and the ppGpp level were determined to evaluate whether SR was initiated. For $\mathrm{N}$ depletion, $M$. aeruginosa cells grown to the logarithmic phase were washed three times with N-deficient BG-11 (without nitrate and sodium nitrate). Then cells were cultivated in conical flasks containing $100 \mathrm{ml}$ of $\mathrm{N}$-deficient BG-11 for different times $(0,0.5,1,2,4$, $6,8,10,12,24,48$, and $72 \mathrm{~h}$ ). For hyperosmotic stress, $\mathrm{NaCl}$ was added to the culture at a final concentration of $20 \mathrm{mg} / \mathrm{ml}$ (2\%, mass fraction) and maintained for different times $(0,0.5$, $1,2,4$, and $6 \mathrm{~h}$ ). For oxidative stress, $\mathrm{H}_{2} \mathrm{O}_{2}$ was added to the culture at a final concentration of $0.2 \mathrm{mg} / \mathrm{ml}(0.02 \%$, mass fraction) for different times $(0,1,2,4,6,8$, and $10 \mathrm{~h})$. For the induction of SHX, SHX was added to the culture at a final 
concentration of $1 \mathrm{~g} / \mathrm{L}$ and maintained for different times $(0,15$, $30,60,90$, and $120 \mathrm{~min})$.

\section{Stress Tolerance}

To test whether the initiation of SR enhances the tolerance of $M$. aeruginosa against environmental stresses, the algal cells were pretreated by $\mathrm{N}$ depletion or SHX for $2 \mathrm{~h}$ to trigger SR and then transferred into different stress conditions. The indicators, such as growth, cell integrity, and ROS, were used to evaluate the protective capability of SR. For hyperosmotic stress, SRtriggering cells by $\mathrm{N}$ depletion or SHX were transferred into BG-11 containing $0,0.5,1.0,1.5,2.0,2.5,3.0,3.5,4.0$, and $4.5 \% \mathrm{NaCl}$ (mass fraction unless otherwise specified). As control, logarithmic cells were transferred to BG-11 culture with the same concentration of $\mathrm{NaCl}$. For oxidative stress, SR-triggering cells by $\mathrm{N}$ depletion or SHX were transferred into BG-11 containing 0, $0.01,0.02,0.03,0.04,0.05,0.06$, and $0.07 \% \mathrm{H}_{2} \mathrm{O}_{2}$, respectively. As control, logarithmic cells were transferred to BG-11 culture with the same concentration of $\mathrm{H}_{2} \mathrm{O}_{2}$.

\section{Functional Complementation of Marsh in E. coli}

3T3TTo identifying the system of SR, the key Marsh gene encoding the synthase and/or hydrolase domains for ppGpp synthesis and hydrolysis in $M$. aeruginosa, was cloned and characterized by functional complementation. The complemental analysis was based on the function restoration of E. coli mutants by transforming the Marsh gene. The E. coli wild-type strain CF1648 and its derived mutants, CF1652 $\left(\mathrm{relA}^{-} \mathrm{spoT}^{+}\right)$and CF1693 $\left(\mathrm{relA}^{-}\right.$spoT $\left.^{-}\right)$, were used for the complement analysis. Due to genetic modification, the CF1693 strain cannot grow on MM agar medium, while CF1652 is unable to grow on MM plate supplemented with amino acids serine, methionine, and glycine (SMG plate). As a positive control, CF1648 can grow on MM and SMG plates. All E. coli strains are able to grow on nutrient-rich medium, such as LB. To test whether MaRSH functions as an $\mathrm{RSH}$, the growth of mutants CF1652 and CF1693 transformed with MaRSH on LB, MM, and SMG was examined. The open reading frame (ORF) of Marsh was amplified by PCR using genomic DNA as a template and then cloned into pET-32a-c(+) between BamHI and HindIII sites, which generated plasmid pET-32a-Marsh. The plasmid 3T3TpET-32a-Marsh was transformed into CF1652 and CF1693. As a control, pET-32a-c(+) empty vector was also transformed into CF1652 and CF1693. The transformed strains were coated to $\mathrm{LB}, \mathrm{SMG}$, and MM plates and grown at $37^{\circ} \mathrm{C}$ for $24 \mathrm{~h}$. Primers used in this study are listed in Supplementary Table S1.

\section{Protein Purification and Enzyme Assay}

Recombinant MaRSH was produced in E. coli BL-21 containing the plasmid pET-32a-Marsh. Cells were pelleted by centrifugation at $12,000 \times g$ for $2 \mathrm{~min}$ at $4^{\circ} \mathrm{C}$. Enzyme was prepared by using the Ni-NTA Spin Kit (QIAGEN, Germany) according to the user protocol and eluted using $300 \mu \mathrm{l}$ of PBS $\left(50 \mathrm{mM} \mathrm{NaH} \mathrm{PO}_{4}\right.$, $300 \mathrm{mM} \mathrm{NaCl}, \mathrm{pH}$ 7.0) containing $500 \mathrm{mM}$ imidazole. The PBS buffer was then changed to Tris- $\mathrm{HCl}$ buffer $(0.1 \mathrm{M}$ Tris- $\mathrm{HCl}$, $\mathrm{pH}$ 8.0, $5 \mathrm{mM}$ DTT, $1 \mathrm{mM}$ EDTA) by using the Zeba Spin
Desalting Columns (Thermo Fisher Scientific, United States). Protein extracts were quantitated at $25^{\circ} \mathrm{C}$ using the TaKaRa BCA Protein Assay Kit (TaKaRa, China).

The synthase and hydrolase activities of MaRSH were assayed according to previous reports (Nanamiya et al., 2008; Ito et al., 2012). Briefly, for synthase activity assay, reaction mixture containing $50 \mu \mathrm{M}$ GDP and $80 \mu \mathrm{M}$ ATP was incubated with $1 \mu \mathrm{g}$ of recombinant $\mathrm{MaRSH}$ at $37^{\circ} \mathrm{C}$ for $20 \mathrm{~min}$ in the presence of $5 \mathrm{mM} \mathrm{Mg}^{2+}$. For hydrolase activity, reaction mixture containing $50 \mathrm{mM}$ Tris- $\mathrm{HCl}(\mathrm{pH} 8.0), 5 \mathrm{mM} \mathrm{Mg}^{2+}, 50 \mu \mathrm{M}$ ppGpp, and $1 \mu \mathrm{g}$ of recombinant $\mathrm{MaRSH}$ was incubated at $37^{\circ} \mathrm{C}$ for $20 \mathrm{~min}$. The mixtures were analyzed by UPLC on a HILIC chromatographic column. ppGpp and GDP products were detected by UV absorbance at $252 \mathrm{~nm}$.

\section{Maximum Fluorescence Yield}

ChI fluorescence was detected using Phyto-PAM (Walz, Germany). Initial $\left(F_{0}\right)$ and maximum $\left(F_{m}\right)$ fluorescence were measured after the cells had been incubated in darkness for $10 \mathrm{~min}$. The maximum effective quantum yield of PSII electron transport was calculated as $F_{v} / F_{m}=F_{0} /\left(F_{m}-F_{0}\right)$.

\section{Laser Scanning Confocal Microscopy (LSCM) Analysis of Reactive Oxygen Species (ROS)}

LSCM was performed according to Owusu-Ansah et al. (2008). The fluorescence of DC-FDA was excited with argon laser at $488 \mathrm{~nm}$ and detected at $530 \mathrm{~nm}$, and autofluorescence of chloroplast was observed simultaneously at $680 \mathrm{~nm}$.

\section{Detection of ROS}

Intracellular ROS in cells were detected using $2^{\prime}, 7^{\prime}$ dichlorodihydrofluorescein diacetate $\left(\mathrm{H}_{2} \mathrm{DCFDA}\right)$ as a fluorescent probe according to Owusu-Ansah et al. (2008). In brief, $M$. aeruginosa cells were harvested and washed three times by PBS. Then, the cells were resuspended in PBS containing $100 \mu \mathrm{M} \mathrm{H} \mathrm{H}_{2} \mathrm{DCFDA}$. The suspension was incubated at $30^{\circ} \mathrm{C}$ in the dark for $30 \mathrm{~min}$ and shaken every $10 \mathrm{~min}$. Then, the mixture was washed again by PBS and resuspended in $400 \mu \mathrm{l}$ of PBS. The fluorescence intensity was measured with the BD FACSCalibur ${ }^{\mathrm{TM}}$ platform (BD Bioscience, United States), with excitation and emission filters of 485 and $530 \mathrm{~nm}$, respectively.

\section{Quantitative RT-PCR (qRT-PCR)}

To determine the expression levels of Marsh and genes encoding antioxidant enzymes such as SOD, POD, GAPX, and GR in $M$. aeruginosa, fresh cells were collected by centrifugation at $10,000 \mathrm{rpm}$ for $10 \mathrm{~min}$ at $4^{\circ} \mathrm{C}$. Total RNA was extracted from $\sim 10^{7}$ cells by using the TRIzol ${ }^{\circledR}$ reagent (Thermo Fisher Scientific, United States). qRT-PCR was run on the 7300 RealTime PCR system (Applied Biosystems, United States) using the PrimeScript ${ }^{\circledR}$ RT reagent kit with gDNA eraser and the SYBR ${ }^{\circledR}$ Premix Ex Taq ${ }^{\mathrm{TM}}$ II Kit (TaKaRa, China). The reaction mixture contained $4 \mu \mathrm{l}$ of cDNA, $0.5 \mu \mathrm{l}$ of forward and reverse primer $\operatorname{mix}(20 \mu \mathrm{M}$ each), $1 \mu \mathrm{l}$ of $50 \times$ ROX reference dye, and $25 \mu \mathrm{l}$ of $2 \times$ TaKaRa SYBR Green PCR mix in a final volume of 50 
$\mu 1$. All reactions were setup in triplicate and every sample was replicated in parallel three times to ensure statistical relevance. The qRT-PCR conditions were as follows: $30 \mathrm{~s}$ at $95^{\circ} \mathrm{C}, 40$ cycles of $30 \mathrm{~s}$ at $95^{\circ} \mathrm{C}$ and $34 \mathrm{~s}$ at $60^{\circ} \mathrm{C}$. Primer specificity was confirmed by RT-PCR amplification, which produced single amplicons with the expected size for each primer set; these amplicons were sequenced to validate their authenticity. Specificity of qRT-PCR was monitored by the presence of dissociation curves with single peaks. Data were analyzed using the SDS software (Applied Biosystems, United States). Primers used in this assay are listed in Supplementary Table S1.

\section{Extraction, Purification, and Detection of ppGpp}

To determine the intercellular level of ppGpp in M. aeruginosa under different stress conditions, 2.4-g fresh cell weight (FCW) of $M$. aeruginosa cells was collected, frozen in liquid nitrogen, crushed, and resuspended in $10 \mathrm{ml}$ of $1 \mathrm{M}$ cool formic acid. The broken cells were vigorously mixed, incubated on ice for $30 \mathrm{~min}$, and then centrifuged at $10,000 \mathrm{rpm}$ for $10 \mathrm{~min}$ at $4^{\circ} \mathrm{C}$. The upper layer was transferred to a new tube and centrifuged to remove cell debris at $10,000 \mathrm{rpm}$ for $10 \mathrm{~min}$ at $4^{\circ} \mathrm{C}$. The aqueous layer was then collected and purified by solid phase extract (SPE). SPE purification was performed by using the OASIS ${ }^{\circledR}$ WAX 3-cc Vac Cartridges (Waters, United States) according to the manufacturer's instructions. Chromatographic separation was performed on a Waters $\mathrm{BEH}$ amide column $(2.1 \times 150 \mathrm{~mm}$, $1.7 \mu \mathrm{m}$ ) according to our published method (Jin et al., 2018).

\section{Extraction and Analysis of Exocellular Polymeric Substances (EPS)}

Polysaccharides, proteins, and humic acids are the main components of the EPS matrix in $M$. aeruginosa (Sheng et al., 2010; Xu et al., 2014). Therefore, total EPS was measured as the sum of these three components. Cells were centrifuged at $8,000 \times g$ for $15 \mathrm{~min}$ at $25^{\circ} \mathrm{C}$. The pellets were resuspended in $10 \mathrm{ml}$ of $0.05 \% \mathrm{NaCl}(\mathrm{pH} 10.0)$, heated at $45^{\circ} \mathrm{C}$ for $4 \mathrm{~h}$, and centrifuged at $12,000 \times g$ for $20 \mathrm{~min}$ at $4^{\circ} \mathrm{C}$. The supernatant was collected for subsequent measurement. Polysaccharide content was measured using the anthrone-sulfuric acid method, with glucose as a standard (Laurentin and Edwards, 2003). Proteins and humic acids were determined according to Frølund (Frølund et al., 1996).

\section{Activity Assays of Antioxidant Enzymes}

To detect the activities of antioxidant enzymes under different stress conditions, $M$. aeruginosa cells were harvested by centrifugation at $2,000 \times g$ for $10 \mathrm{~min}$ at $25^{\circ} \mathrm{C}$, washed with PBS buffer, and collected by centrifugation. The cells were resuspended with PBS buffer, sonicated, and centrifuged at $15,000 \times g$ for $20 \mathrm{~min}$ at $4^{\circ} \mathrm{C}$. The supernatant was used for activity assays. The activities of peroxidase (MaPOD), glutathione peroxidase (MaGAPX), superoxide dismutase (MaSOD), and glutathione reductase (MaGR) in $M$. aeruginosa were assayed using POD and GAPX, SOD, and GR detection kits (Beyone, China) according to the user protocol.

\section{Sequence Analysis}

Sequence blast was performed using BLAST software ${ }^{1}$. Multiple alignments were conducted using Clustal X2.1. Secondary domains were predicted by Conserved Domain Search ${ }^{2}$. Homology modeling was performed by the SWISS-MODEL server $^{3}$. Sequences used for multiple alignments are listed in Supplementary Table S2.

\section{Statistical Analysis}

The data were processed by one-way analysis of variance using SPSS version 13.0 (SPSS, United States). Summary statistics were expressed as means $\pm \mathrm{SD}$.

\section{RESULTS}

\section{Characterization of the SR System in M. aeruginosa}

Although the homolog of relA/spoT is annotated in the genome of M. aeruginosa NIES-843 (NC_010296.1), at present, its authentic function is unknown. Therefore, the sequence, designated as MaRSH according to its dual functions, was isolated and functionally characterized. Using $M$. aeruginosa genomic DNA as template, the ORF of Marsh was amplified, which encodes a polypeptide with 765 aa in length. This MaRSH shows a high level of similarity to the RelA/SpoT superfamily from eubacteria and plants (Figure 1A). It has typical secondary structures of the RelA/SpoT superfamily, e.g., HD domain (hydrolase), RelA_SpoT domain (synthase), TGS domain, and ACT domain. Using homology modeling, the protein structure of MaRSH was constructed. The hydrolase and synthase domains were mapped onto the model using Streptococcus equisimilis Rel (PDB ID: 1vj7) as a template (Figure 1B). These results implied that MaRSH might be a RelA/SpoT-like enzyme.

The function of MaRSH was determined by functional complementation in E. coli strains CF1652 (relAspoT ${ }^{-}$), CF1693 (relA ${ }^{-}$spot ${ }^{-}$), and CF1648 (wild type). All these E. coli strains could grow on an LB plate (data not shown). CF1652 could not grow on an SMG plate, but CF1652 transformed with pET32a-MaRSH restored the growth on an SMG plate (Figure 1C). Meanwhile, as a RelA/SpoT double-mutant strain, CF1693 could not grow on the MM plate (Xiao et al., 1991). As shown in Figure 1C, CF1693 transformed with the pET-32a$c(+)$ empty vector could not grow on an MM plate, while transforming pET-32a-MaRSH into CF1693 could restore the growth on an MM plate (Figure 1C). These results indicated that MaRSH could complement both relA- spoT $^{+}$and relA- $s p o T^{-}$ phenotypes and function as an RSH, i.e., as a (p)ppGpp synthase and hydrolase bifunctional enzyme. The in vitro activities of MaRSH were determined (Figure 1D). In the presence of $\mathrm{Mn}^{2+}$, MaRSH hydrolyzed ppGpp into GDP. When $\mathrm{Mg}^{2+}$ was present, MaRSH synthesized ppGpp using ATP and GDP as substrates. These results finally indicated that (1)

\footnotetext{
${ }^{1}$ http://blast.ncbi.nlm.nih.gov/

${ }^{2}$ https://www.ncbi.nlm.nih.gov/Structure/cdd/wrpsb.cgi

${ }^{3}$ https://swissmodel.expasy.org/
} 

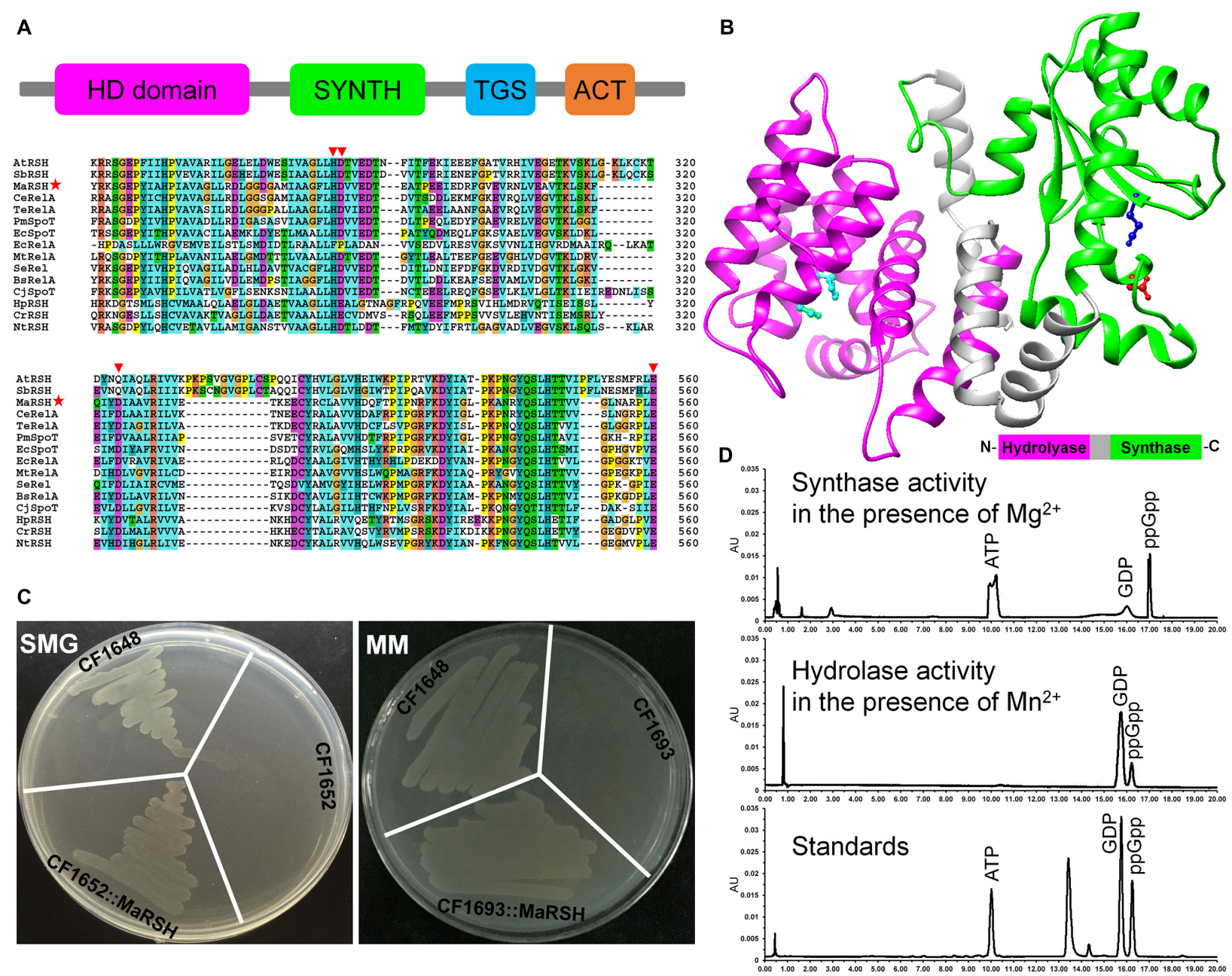

FIGURE 1 | Characterization of relA/spoT homologous gene Marsh in M. aeruginosa. (A) Secondary conserved domains and sequence alignment of MaRSH. Inverted triangles indicate key regulatory amino acid residues. Red stars indicated the sequence of MaRSH. (B) Homology modeling of MaRSH. Key regulatory amino residues are indicated by ball-and-stick model, e.g., $\mathrm{H}_{99} \mathrm{D}_{100}$ of the hydrolase domain in cyan, $\mathrm{D}_{287}$ of the synthase domain in red, and $\mathrm{E}_{347}$ for metal binding in mazarine. (C) Functional complementation of MaRSH. (D) In vitro activities of MaRSH. In the presence of Mg ${ }^{2+}$, the enzyme utilized ATP and GDP as substrates to synthesize ppGpp (upper panel), while in the presence of $\mathrm{Mg}^{2+}$, MaRSH displayed hydrolase activity to hydrolyze ppGpp into GDP (lower panel).

MaRSH is a bifunctional (p)ppGpp synthetase/guanosine- $3^{\prime}, 5^{\prime}$ bis(diphosphate) $3^{\prime}$-pyrophosphohydrolase; (2) the synthase activity of $\mathrm{MaRSH}$ is $\mathrm{Mg}^{2+}$ dependent while the hydrolase activity is $\mathrm{Mn}^{2+}$ dependent; and (3) sophisticated regulation between hydrolase and synthase activities implies a complex regulation of SR in stress response.

\section{N Depletion Triggers SR in M. aeruginosa}

The effect of $\mathrm{N}$ depletion, hyperosmotic stress, oxidative stress, and the classic SR inducer SHX on the transcription of Marsh was determined (Figure 2). When cells were transferred to $\mathrm{N}$-deficient BG-11 ( $\left.\mathrm{N}^{-}\right)$, the transcription of Marsh was rapidly upregulated to more than twofold within $30 \mathrm{~min}(p<0.05)$ and reached its maximum (about 12 -fold) at $2 \mathrm{~h}(p<0.01)$, compared to the control. Similarly, the transcriptional expression of Marsh was induced to the highest level (almost 10-fold higher than the control group) by SHX after $30 \mathrm{~min}(p<0.05)$. In contrast,
Marsh was inhibited by $\mathrm{NaCl}$ and $\mathrm{H}_{2} \mathrm{O}_{2}$. It is worth noting that the inhibition could be reversed by pretreatment with $\mathrm{N}$ depletion $\left(\mathrm{N}^{-}+\mathrm{NaCl}\right.$ and $\left.\mathrm{N}^{-}+\mathrm{H}_{2} \mathrm{O}_{2}\right)$ or SHX (SHX $+\mathrm{NaCl}$ and $\mathrm{SHX}+\mathrm{H}_{2} \mathrm{O}_{2}$ ). When cells were exposed to $2.0 \% \mathrm{NaCl}$ or $0.04 \%$ $\mathrm{H}_{2} \mathrm{O}_{2}$ for $2 \mathrm{~h}$, Marsh was downregulated to 28.7 or $31.2 \%$ of the control, respectively. While in cells pretreated with $\mathrm{N}$ depletion or SHX, the transcription of Marsh under the corresponding conditions was restored to near normal levels $(p<0.05)$ or was obviously $(p<0.05)$ upregulated.

To further clarify whether $M$. aeruginosa triggered SR in response to $\mathrm{N}$ depletion, the content of ppGpp in cells was determined. As shown in Figure 2F, in cells subjected to $\mathrm{N}$ depletion for $2 \mathrm{~h}$ or SHX for $30 \mathrm{~min}$, in vivo ppGpp significantly increased to $26.33 \pm 1.91 \mathrm{pmol} / \mathrm{g} \mathrm{FCW}(p<0.01)$ or $35.29 \pm 2.84 \mathrm{pmol} / \mathrm{g}$ FCW $(p<0.05)$, compared to the control $(6.24 \pm 0.25 \mathrm{pmol} / \mathrm{g} \mathrm{FCW})$. By contrast, high salinity led to a marked $(p<0.05)$ decrease in ppGpp $(2.42 \pm 0.55 \mathrm{pmol} / \mathrm{g}$ 

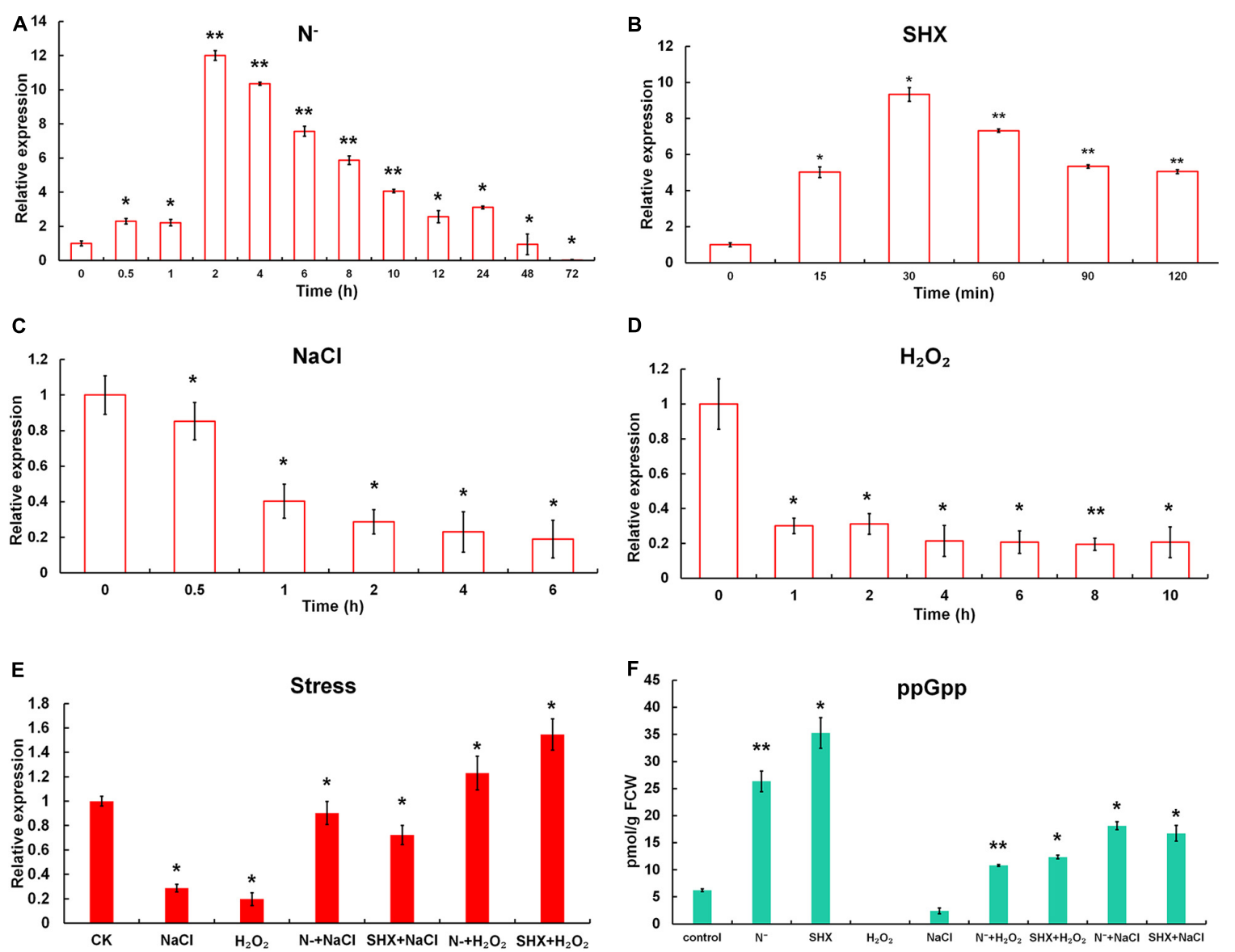

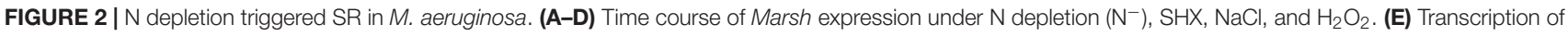
Marsh in $\mathrm{NaCl}$ - and $\mathrm{H}_{2} \mathrm{O}_{2}$-stressed cells pretreated with $\mathrm{N}$ depletion $\left(\mathrm{N}^{-}+\mathrm{NaCl}\right.$ and $\left.\mathrm{N}^{-}+\mathrm{H}_{2} \mathrm{O}_{2}\right)$ or $\mathrm{SHX}\left(\mathrm{SHX}+\mathrm{NaCl}\right.$ and $\left.\mathrm{SHX}+\mathrm{H} 2 \mathrm{O}_{2}\right)$. (F) Endogenous ppGpp synthesized under stresses. Error bars indicate the standard deviation (SD) of the mean $(n=3)$ for Marsh transcription analysis or $n=6$ for endogenous ppGpp determination. ${ }^{\star} p<0.05 ;{ }^{* *} p<0.01$.

FCW); no ppGpp was detected in cells treated by oxidative stress. However, pretreatment with $\mathrm{N}$ depletion or SHX reversed the inhibitory effect; i.e., ppGpp increased to $10.81 \pm 0.18$ $\left(\mathrm{N}^{-}+\mathrm{H}_{2} \mathrm{O}_{2}\right), 11.26 \pm 0.21\left(\mathrm{SHX}+\mathrm{H}_{2} \mathrm{O}_{2}\right), 18.13 \pm 0.72$ $\left(\mathrm{N}^{-}+\mathrm{NaCl}\right)$, and $16.74 \pm 1.44 \mathrm{pmol} / \mathrm{g} \mathrm{FCW}(\mathrm{SHX}+\mathrm{NaCl})$. These results indicated that (1) both $\mathrm{N}$ depletion and SHX initiated SR; (2) as a typical SR inducer, SHX could be used as a positive control; (3) hyperosmotic and oxidative stresses inhibited SR in $M$. aeruginosa; and (4) pretreatment with $\mathrm{N}$ depletion or SHX compensated SR inhibition by hyperosmotic or oxidative stress.

\section{SR Maintains Membrane Integrity to Alleviate Cell Viability Inhibition by Environmental Stress}

Gradual cell growth arrest was observed in cells exposed to hyperosmotic or oxidative stress over time, whereas $\mathrm{N}$ depletion or SHX had little influence on the growth (Figures $3 \mathbf{A}, \mathbf{B}$ ). Pretreatment with $\mathrm{N}$ depletion for $2 \mathrm{~h}$ or SHX for $30 \mathrm{~min}$ significantly $(p<0.05)$ alleviated cell growth arrest induced by hyperosmotic or oxidative stress. Hyperosmolarity induced by high salinity can destroy cell membrane to inhibit cell growth (Zhu, 2016). Therefore, the growth inhibition by salt stress is likely to be related to membrane damage. Visually, high salinity changed the color of cell culture from blue-greenish to brown-yellowish (Figures 3C,F), while pretreatment with $\mathrm{N}$ depletion (Figure 3D) or SHX (Figure 3G) had no visual change. Moreover, the supernatant of NaCl-treated cells showed blue, and the precipitate contained some debris in the bottom of the tube (Figures $\mathbf{3 E}, \mathbf{H}$ ), indicating that membrane permeability increased, and some cells were lysed under salt stress. Whereas pretreatment with $\mathrm{N}$ depletion or SHX had little effect on the cells, as the supernatant of cells was colorless, no cell debris was found in the precipitate (Figures $\mathbf{3 E}, \mathbf{H}$ ).

\section{SR Promotes Cluster Formation in M. aeruginosa Against Environmental Stress}

$M$. aeruginosa only exists as a single cell or a few paired cells in laboratory culture. To be exact, it lost the ability to 

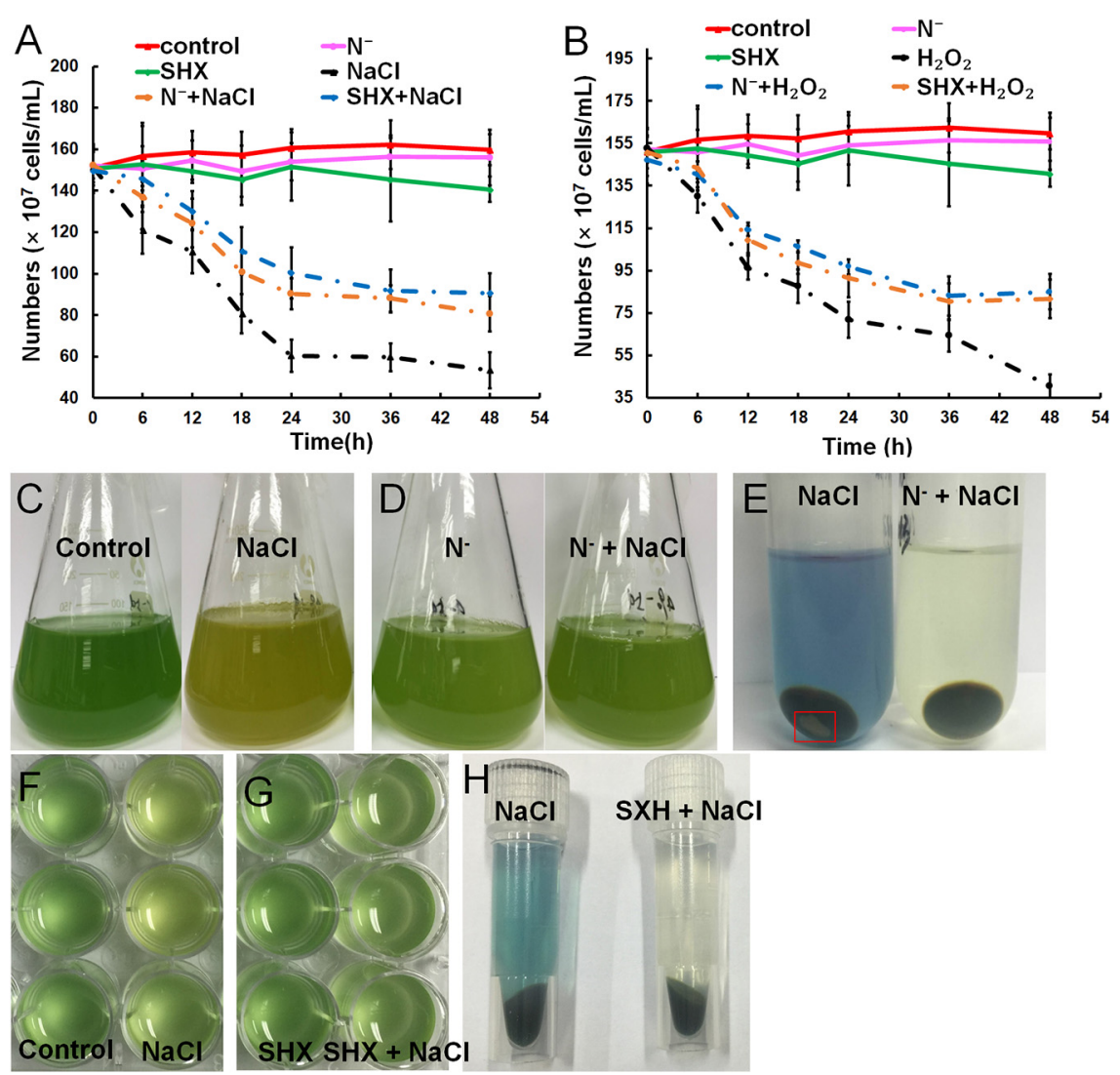

FIGURE 3 | Relief of stress-induced growth inhibition by SR through maintaining membrane integrity. (A,B) Growth curves of $M$. aeruginosa cells under stresses. (C-H) M. aeruginosa cell cultures in stress conditions. Error bars indicate the standard deviation (SD) of the mean $(n=6)$.

cluster in the laboratory (Figure 4A). However, the cluster could be reconstituted by $\mathrm{NaCl}$ (Figure 4B), $\mathrm{H}_{2} \mathrm{O}_{2}$ (Figure 4C), $\mathrm{N}$ depletion (Figure 4D), and SHX (Figure 4E), which was accompanied by production of EPS, i.e., $8.53 \pm 0.87(p<0.05)$, $9.42 \pm 1.64(p<0.05), 10.80 \pm 0.60(p<0.05)$, and $25.41 \pm 2.72 \mathrm{mg} / \mathrm{g}$ FCW $(p<0.05)$, respectively, compared to the control $(7.36 \pm 0.42 \mathrm{mg} / \mathrm{g}$ FCW) (Figure 4J). Pretreatment with $\mathrm{N}$ depletion or SHX enlarged the size of the cluster and further $(p<0.05)$ enhanced EPS production to $26.57 \pm 3.72$ $\left(\mathrm{N}^{-}+\mathrm{NaCl}\right.$, Figure 4F), $19.36 \pm 2.04\left(\mathrm{~N}^{-}+\mathrm{H}_{2} \mathrm{O}_{2}\right.$, Figure 4G), $32.81 \pm 3.05(\mathrm{SHX}+\mathrm{NaCl}$, Figure $4 \mathrm{H})$, and $24.52 \pm 1.92 \mathrm{mg} / \mathrm{g}$ FCW ( $\mathrm{SHX}+\mathrm{H}_{2} \mathrm{O}_{2}$, Figure 4I). These results suggested that SR promoted cluster formation by enhancing EPS production to withstand environmental stress.

\section{SR Maintains Photosynthetic Performance Under Stress}

The photochemical reaction efficiency of PSII, $F_{v} / F_{m}$, is commonly used to determine metabolic disorder of cells subjected to environmental stress, which describes the state of photodamage (Baker, 2008). As shown in Figures 5A,B, although the $F_{v} / F_{m}$ ratio in all treatment groups showed a decreasing trend along with the increasing exposure concentrations, the $F_{v} / F_{m}$ ratios of SR-induced cells $\left(\mathrm{N}^{-}+\mathrm{NaCl}, \mathrm{SHX}+\mathrm{NaCl}\right.$,
$\mathrm{N}^{-}+\mathrm{H}_{2} \mathrm{O}_{2}$, and $\mathrm{SHX}+\mathrm{H}_{2} \mathrm{O}_{2}$ ) were higher than those of non-SR-induced cells $\left(\mathrm{NaCl}\right.$ and $\left.\mathrm{H}_{2} \mathrm{O}_{2}\right)$ at every corresponding concentration. Furthermore, in the groups of $\mathrm{N}^{-}+\mathrm{NaCl}$ and $\mathrm{SHX}+\mathrm{NaCl}$, the $\mathrm{F}_{v} / \mathrm{F}_{m}$ ratios declined to zero at $\mathrm{NaCl}$ concentrations of 4.0 and $3.5 \%$, respectively, while those of $\mathrm{NaCl}-$ treated cells declined to zero at $3.0 \%$. In other words, when $\mathrm{SR}$ was triggered by $\mathrm{N}$ depletion or SHX, the salt tolerance of $M$. aeruginosa (the minimum salt concentration leading to the reduction of the $F_{v} / F_{m}$ ratio to zero) increased at 1.0 and $0.5 \%$, respectively. A similar result was observed in $\mathrm{H}_{2} \mathrm{O}_{2}$-treated cells: $\mathrm{N}^{-}+\mathrm{H}_{2} \mathrm{O}_{2}$ and $\mathrm{SHX}+\mathrm{H}_{2} \mathrm{O}_{2}$ at 0.065 and $0.066 \%$, respectively, and $\mathrm{H}_{2} \mathrm{O}_{2}$ at $0.05 \%$.

\section{SR Reduces Oxidative Damage by Environmental Stress}

Environmental stress disrupts cellular homeostasis and leads to the generation of ROS (Bowler et al., 1992; Polle, 2001). ROS attacks cellular macromolecules, such as proteins, nucleic acids, and membrane lipids. Therefore, ROS is commonly used as a reliable indicator to evaluate cell damage by stress. As depicted in Figures 5C,D, the level of ROS in $\mathrm{NaCl}$ - or $\mathrm{H}_{2} \mathrm{O}_{2}$-treated cells soared with the rising concentrations and reached about 10 fold of the control at $4 \% \mathrm{NaCl}$ or $0.06 \% \mathrm{H}_{2} \mathrm{O}_{2}$. Although the fluorescent intensities of ROS in SR-induced cells $\left(\mathrm{N}^{-}+\mathrm{NaCl}\right.$, 

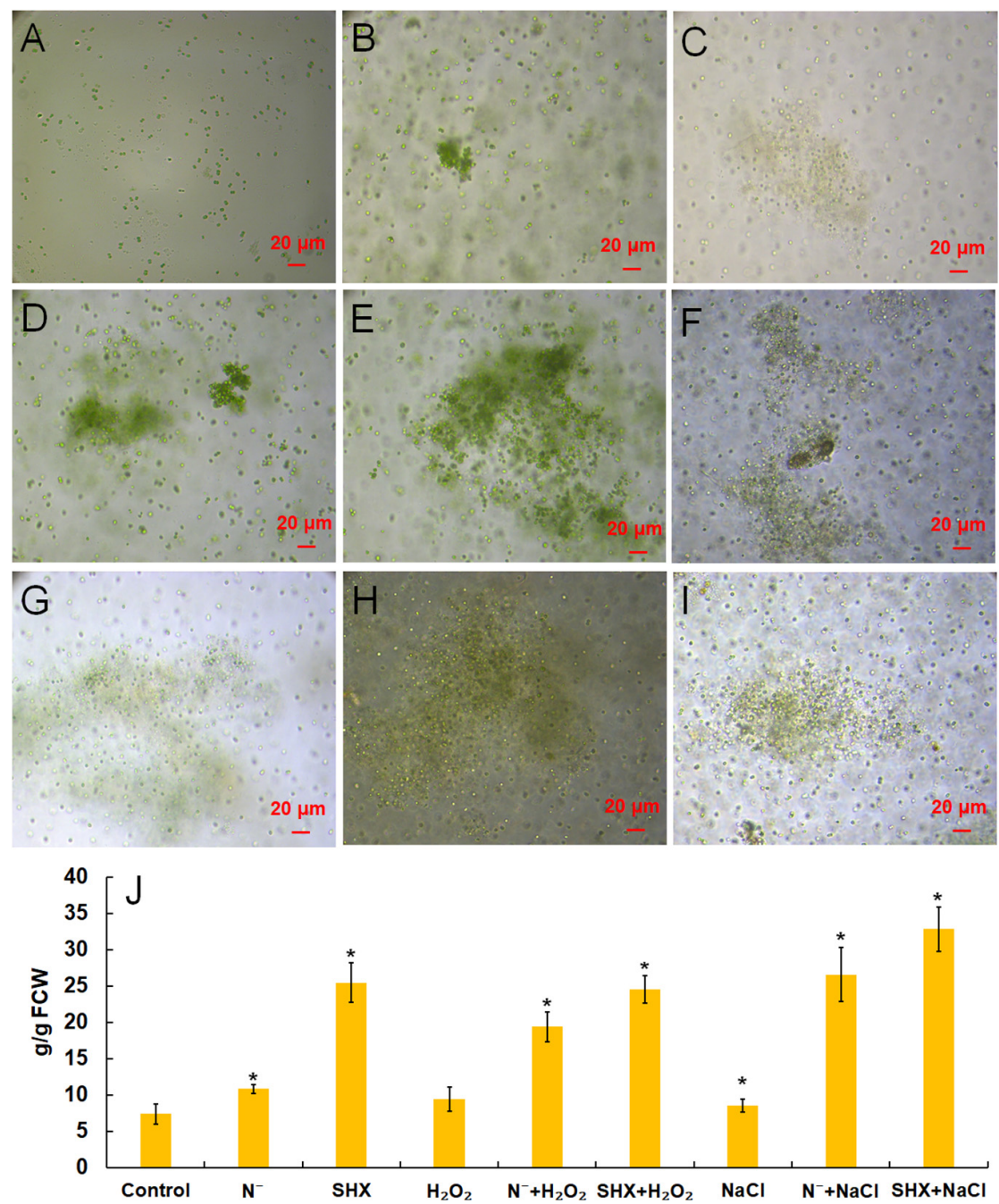

FIGURE 4 | SR promoted the formation of cell clusters and EPS production. (A-I) Control, $\mathrm{NaCl}_{2} \mathrm{H}_{2} \mathrm{O}_{2}, \mathrm{~N}$ depletion $\left(\mathrm{N}^{-}\right), \mathrm{SHX}, \mathrm{N}^{-}+\mathrm{NaCl}^{-} \mathrm{N}^{-}+\mathrm{H}_{2} \mathrm{O}_{2}$, $\mathrm{SHX}+\mathrm{NaCl}$, and $\mathrm{SHX}+\mathrm{H}_{2} \mathrm{O}_{2}$. (J) Contents of EPS under stresses. Error bars indicate the standard deviation (SD) of the mean ( $\left.n=6\right)$. ${ }^{*} p<0.05$.

$\mathrm{N}^{-}+\mathrm{H}_{2} \mathrm{O}_{2}$, and $\mathrm{SHX}+\mathrm{H}_{2} \mathrm{O}_{2}$ ) also increased with the increasing exposure concentrations, the levels were significantly $(p<0.05$ or 0.01$)$ lower than those in non-SR-induced cells $(\mathrm{NaCl}$ and $\mathrm{H}_{2} \mathrm{O}_{2}$ ) at every corresponding concentration. The intracellular ROS was visualized by ROS fluorescence. Before $\mathrm{NaCl}$ or $\mathrm{H}_{2} \mathrm{O}_{2}$ stressing, the ROS signal was low in SR-induced cells $\left(\mathrm{N}^{-}\right.$and SHX) and the control (Figures 6A,C,E,G,I,K). After stressing, the ROS signal increased remarkably in non-SR-induced cells (Figures 6B,H), while in SR-induced cells, the ROS signal slightly strengthened and was far below that in non-SR-induced cells (Figures 6D,F,J,L). These data suggested that SR inhibited ROS formation induced by stress.

\section{SR Upregulates Stress-Related Enzymes}

Transcription of typical antioxidant enzymes, such as MaPOD, MaGAPX, MaSOD, and MaGR, was determined by qRT-PCR. MaPOD, MaGAPX, MaSOD, and MaGR were induced by $\mathrm{N}$ depletion or SHX (Figure 7A). When these SR-induced cells were subjected to stresses $\left(\mathrm{N}^{-}+\mathrm{NaCl}, \mathrm{SHX}+\mathrm{NaCl}, \mathrm{N}^{-}+\mathrm{H}_{2} \mathrm{O}_{2}\right.$, and $\mathrm{SHX}+\mathrm{H}_{2} \mathrm{O}_{2}$ ), the upregulation was maintained, though lower than that of $\mathrm{N}^{-}$and SHX. Generally, transcription of these antioxidant enzymes in SR-induced cells was higher than that in non-SR-induced cells $\left(\mathrm{NaCl}\right.$ and $\left.\mathrm{H}_{2} \mathrm{O}_{2}\right)$. In vitro activity of these enzymes was also determined. An overall correlation of activity to transcription was observed (Figure 7B).

In PSII, a dynamic cycle of photodamage and photorepair is achieved by the degradation and resynthesis of D1, which binds all redox-active components in electron transfer. Abnormal turnover of D1 could lead to ROS burst by hindering electron transfer. D1 is regulated by SR at the transcriptional level in cyanobacteria and plants (Huang et al., 2002; Mulo et al., 2009; Hess et al., 2014; Maekawa et al., 2015). Therefore, the transcription of D1-encoding MaPsbA3 was determined. Compared to the control, MaPsbA3 was upregulated to 7.47fold $(p<0.001)$ in $\mathrm{N}$-depletion cells and 2.57-fold $(p<0.01)$ in SHX-treated cells. While $\mathrm{NaCl}$ and $\mathrm{H}_{2} \mathrm{O}_{2}$ stresses markedly 

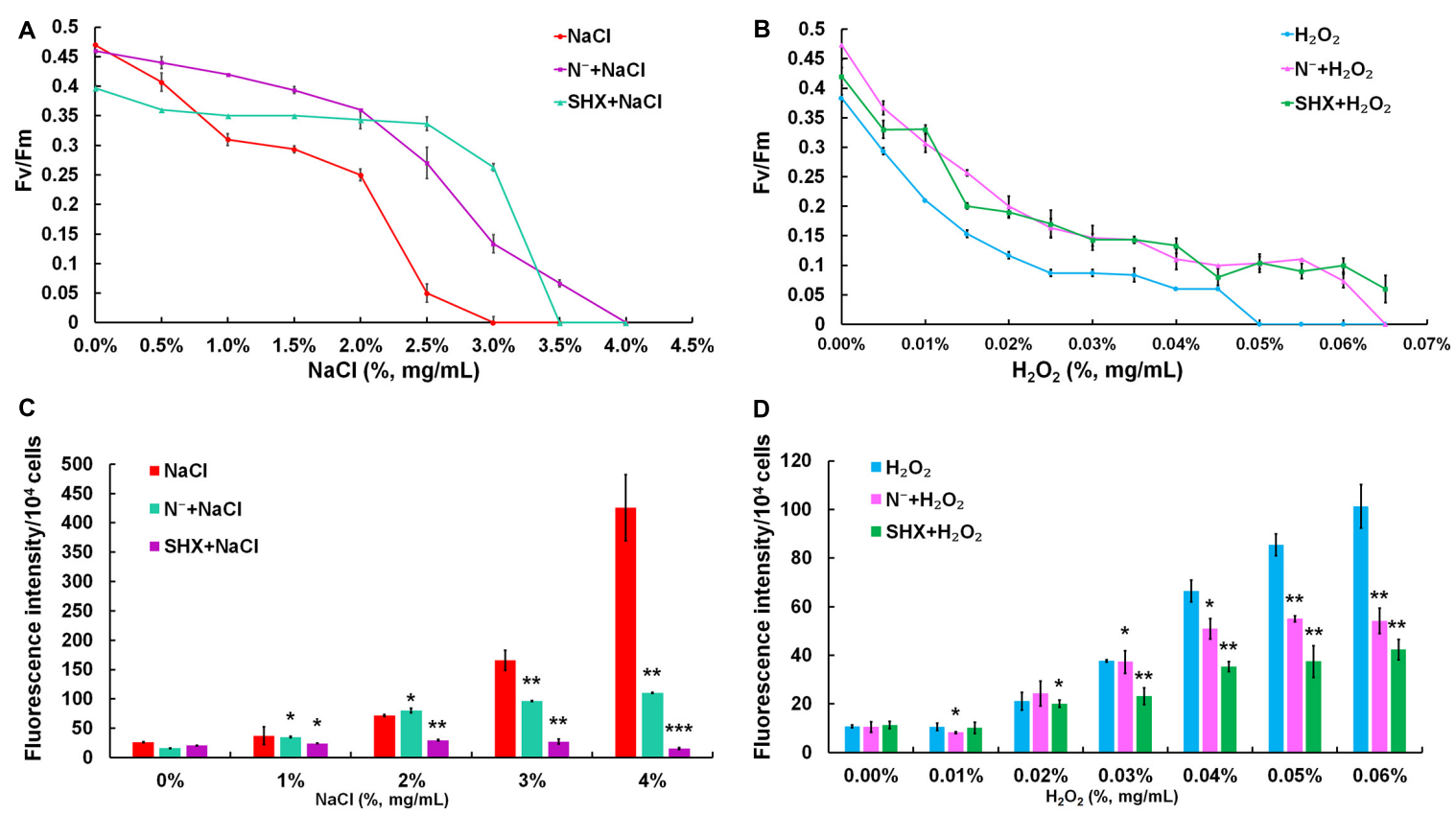

FIGURE 5 | SR maintained photosynthetic performance and reduced ROS production. (A,B) Maximum quantum yield $\left(F_{v} / F_{m}\right)$ induced by stresses. $(\mathbf{C}, \mathbf{D})$ Dose-dependent ROS levels in M. aeruginosa under stresses. Error bars indicate the standard deviation (SD) of the mean $(n=6) .{ }^{\star} p<0.05 ;{ }^{* \star} p<0.01 ;{ }^{* \star \star} p<0.001$.

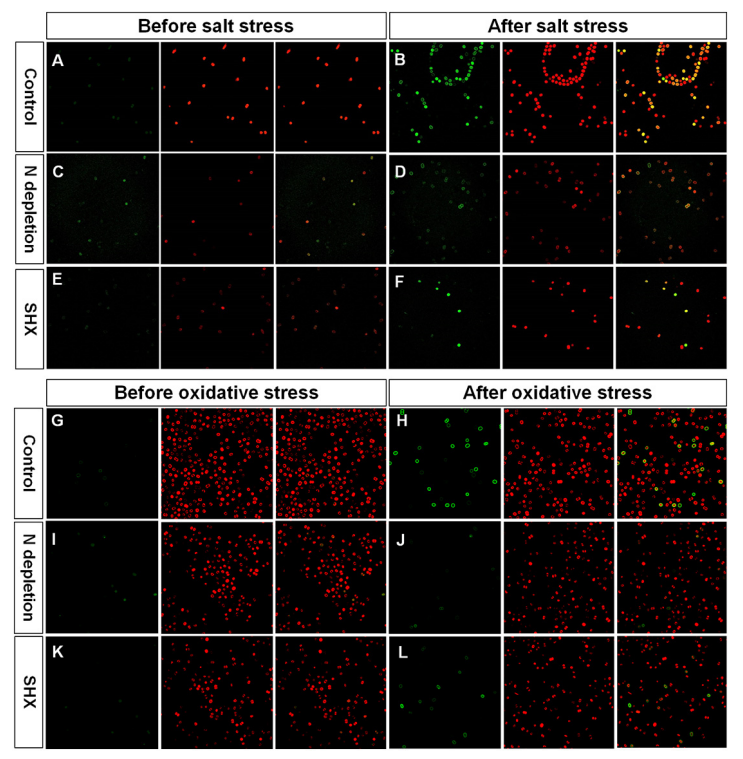

FIGURE 6 | Fluorescence of ROS and chlorophyll in $M$. aeruginosa cells under stresses. (A-L) Control, $\mathrm{NaCl}, \mathrm{N}$ depletion ( $\left.\mathrm{N}^{-}\right), \mathrm{SHX}, \mathrm{N}^{-}+\mathrm{NaCl}, \mathrm{N}^{-}+\mathrm{H}_{2} \mathrm{O}_{2}$, $\mathrm{SHX}+\mathrm{NaCl}$, and $\mathrm{SHX}+\mathrm{H}_{2} \mathrm{O}_{2}$. Left panels: ROS fluorescence (green). Middle panels: Chlorophyll autofluorescence (red). Right panels: Merged images of ROS fluorescence and chlorophyll autofluorescence (yellow).

reduced MaPsbA3 transcripts to 0.47 -fold $(p<0.05)$ and 0.72 fold $(p<0.01$ ), respectively (Figure 7C), pretreatment with $\mathrm{N}$ depletion or SHX released the inhibition by $\mathrm{NaCl}$ or $\mathrm{H}_{2} \mathrm{O}_{2}$, as the transcription of MaPsbA3 was recovered to 1.69 -fold $(p<0.05)$
$\left(\mathrm{N}^{-}+\mathrm{NaCl}\right), 2.19$-fold $(p<0.05)(\mathrm{SHX}+\mathrm{NaCl}), 1.34$-fold $(p<0.05)\left(\mathrm{N}^{-}+\mathrm{H}_{2} \mathrm{O}_{2}\right)$, and 1.28-fold $(p<0.05)\left(\mathrm{SHX}+\mathrm{H}_{2} \mathrm{O}_{2}\right)$. SR upregulated the transcription of MaPsbA3 and improved the turnover of D1 and, thus, enhanced photorepair.

\section{DISCUSSION}

\section{N-Depletion-Induced SR Confers Stress Tolerance to $M$. aeruginosa}

The present study provides evidence that SR triggered by $\mathrm{N}$ depletion or SHX conferred $M$. aeruginosa cells enhanced tolerance to environmental stress. The initiation of SR exerted multiple protective effects on $M$. aeruginosa cells to minimally disturb cellular physiology and prolong cell survival in stress conditions. Several factors contributed to the stress resistance, e.g., maintaining membrane integrity (Figure 3), segregating cells from harmful microenvironment by forming cell clusters which may be indicative of colonies rich in EPS (Figure 4), improving photosynthetic performance (Figure 5) by upregulating D1 synthesis (Figure 7C), and reducing endogenous ROS production (Figures 5, 6) by activating ROS-scavenging enzymes (Figure 7). In the state of SR, cellular morphology was changed markedly from a single-cell form to a multicellular colony (Figure 4). The colony of $M$. aeruginosa was wrapped by a cloud of EPS matrix, which functioned as a barrier between cells and the external environment to segregate cells from hazardous substances. Under the protection of EPS, M. aeruginosa cells were not bleached and lysed by high concentrations of $\mathrm{NaCl}$ (Figure 3). In addition, EPS can also contribute to the formation of $M$. aeruginosa 

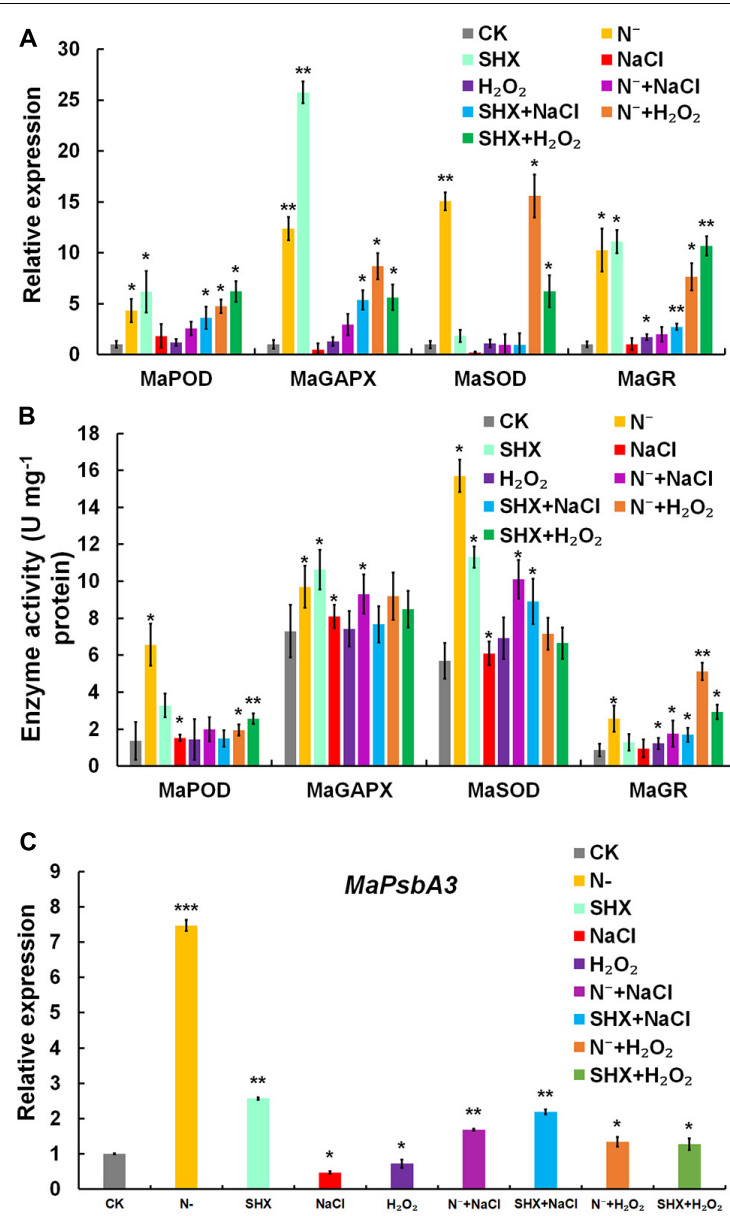

FIGURE 7 | SR enhanced ROS elimination of ROS by upregulating the expression of stress-related genes. (A) Transcription of stress-related genes under stresses. (B) Enzyme activity of stress-related genes under stresses. (C) Transcription of D1-encoding MaPsbA3 under stresses. Error bars indicate the standard deviation (SD) of the mean $(n=3)$. ${ }^{*} p<0.05$;

${ }^{\star *} p<0.01 ;{ }^{\star \star \star} p<0.001$.

aggregates and the final development of bloom from aggregates (Xu et al., 2014). Furthermore, SR-induced cells covered by EPS were less susceptible to damage by $\mathrm{NaCl}$ and $\mathrm{H}_{2} \mathrm{O}_{2}$ and therefore exhibited a higher $F_{v} / F_{m}$ ratio (Figure 5). SR also strengthened D1 biosynthesis to further enhance photosynthesis (Figure 7). Higher photosynthetic performance reduced electron leak during electron transfer reaction in the chloroplast and subsequently decreased ROS production (Figures 5, 6). Besides, SR enhanced ROS elimination by upregulating ROS-scavenging enzymes (Figure 7). Moreover, the robust repair of photodamage through upregulating MaPsbA3 may mitigate the toxic effect of ROS (Figure 7). Therefore, a combination of reduced ROS production with enhanced ROS scavenging ability enabled cells to safeguard from ROS damage during stressing. Since overaccumulation of ROS can lead to irreversible damage and even may ultimately kill cells by reacting with a large number of biomolecules (Mittler, 2002), we assume that reducing the level of ROS as much as possible is one adaptation of SR-induced cells to resist stress.
Similar results were observed in $P$. aeruginosa. SR activated by $\mathrm{N}$ depletion enhanced tolerance of $P$. aeruginosa to antibiotics by increasing the activities of SOD and catalase (Nguyen et al., 2011). N depletion may endow cells with tolerance to acute environmental stress by initiating SR.

\section{The Role of SR in Cyanobacterial Blooms}

In the past decade, aquatic scientists advocated that besides $\mathrm{P}$ input reducing, the need to reduce $\mathrm{N}$ input should also be considered to control cyanobacterial blooms (Conley et al., 2009; Paerl et al., 2011). However, evidences show that $\mathrm{N}$ limitation cannot effectively control cyanobacterial blooms; instead, $\mathrm{N}$ limitation induces the bloom of N-fixation cyanobacteria (Conley et al., 2009; Paerl et al., 2011). For example, controlling $\mathrm{N}$ inputs actually aggravated the dominance of $\mathrm{N}$-fixing cyanobacteria, and then new $\mathrm{N}$ fixed by $\mathrm{N}$-fixing cyanobacteria replenished the $\mathrm{N}$ pool to promote the growth of non-N-fixing cyanobacteria in Lake 227 in northwestern Ontario, Canada (Schindler et al., 2008). In Lake Mendota (Wisconsin, United States), a decline in dissolved inorganic nitrogen resulted in the dominance of N-fixing cyanobacteria (e.g., Aphanizomenon) (Beversdorf et al., 2013). Although the effectiveness of controlling $\mathrm{N}$ to eliminate eutrophication had been observed in macroscale, the cellularlevel mechanism underlying the ecological event is still poorly understood. The present study and several previous reports imply that SR may be involved in this process.

It seems that SR is widely distributed in cyanobacteria since bioinformatics analysis found that many cyanobacteria possess RSH analogs (Atkinson et al., 2011). N limitation probably triggers $\mathrm{SR}$ in cyanobacteria to regulate physiological activities. SR was proven to regulate stable RNA synthesis (Smith and Carr, 1977); and $\mathrm{N}$ depletion could induce ppGpp synthesis in Anacystis nidulans (Friga et al., 1981). In Anabaena cylindrical, SR was also triggered by $\mathrm{N}$ depletion (Akinyanju and Smith, 1979, 1987). Non-N-fixing and N-fixing cyanobacteria have developed different strategies to cope with $\mathrm{N}$ depletion, both involved SR. In non-N-fixing cyanobacteria, SR regulates cells to divert cellular resource from rapid growth to survival in natural water bodies, in which multiple stresses often occur simultaneously. For example, in this study, $M$. aeruginosa SR upregulated stress-related genes in response to N depletion. Synechococcus sp. differentiated to nonpigmented resting cells, known as chlorosis, to survive prolonged periods of $\mathrm{N}$ depletion (Sauer et al., 2001; Klotz et al., 2015). The formation of chlorosis under $\mathrm{N}$ depletion involved initiation of SR. In the chlorosis state, cells could live for several months under $\mathrm{N}$ depletion without loss of cell viability, and growth could be reinitiated immediately once $\mathrm{N}$ was supplied. SR also regulated the acclimation of $S$. elongates to darkness.

In $\mathrm{N}$-fixing cyanobacteria, $\mathrm{SR}$ is involved in biological $\mathrm{N}$ fixation. $\mathrm{N}$ limitation encourages replacement of non- $\mathrm{N}$ fixing with $\mathrm{N}$-fixing cyanobacteria, such as Anabaena sp. and Aphanizomenon sp. (Smith, 1983, 1990; Schindler et al., 2008). These $\mathrm{N}$-fixing cyanobacteria finally bring new $\mathrm{N}$ into the waterbody. It is reported that biological $\mathrm{N}$ fixation by cyanobacteria could reach 130-400 KT and support $45 \%$ of $\mathrm{N}$ accumulation in sediment in the Gotland Sea (Struck et al., 2004). It is found that $\mathrm{N}$ fixation was proportional to heterocyst numbers 
in filamentous cyanobacteria (Findlay et al., 1994) and SR was involved in heterocyst development (Wood and Haselkorn, 1980; Zhang et al., 2013). A representative example is Anabaena sp., in which SR was triggered by $\mathrm{N}$ depletion; SR then activated the formation of the N-fixing heterocyst, while the mutant loss of SR could not form the heterocyst (Zhang et al., 2013). Input of new $\mathrm{N}$ by $\mathrm{N}$-fixing cyanobacteria may stimulate subsequent blooms of non-N-fixing cyanobacteria and other benthic algae. When new fixed $\mathrm{N}$ arrived in the waterbody, the resting non-N-fixing cells resumed to grow rapidly and alternatively became dominant (Paerl and Otten, 2016; Pérez et al., 2017; Chia et al., 2018).

Since SR is conserved in nearly all bacteria and N depletion triggers SR in many cyanobacteria, we speculate that SR may be involved in the succession of cyanobacterial blooms during $\mathrm{N}$ limitation in marine environments and some trophic lakes. SR protects cyanobacteria from environmental stress, which allows the cells to survive and sustain non-N-fixing cyanobacterial population to prepare for the next bloom, when new $\mathrm{N}$ sources is supplied by $\mathrm{N}$-fixing cyanobacteria. That is, SR functions to (1) steady non-N-fixing cyanobacterial population and (2) promote new $\mathrm{N}$ supply by $\mathrm{N}$-fixing cyanobacteria. Therefore, our work provided evidence at the cellular level that $\mathrm{N}$ limitation is ineffective to control cyanobacterial blooms. The alternated dominance between $\mathrm{N}$-fixing and non-N-fixing cyanobacteria may be coordinated by SR.

\section{DATA AVAILABILITY STATEMENT}

All datasets generated for this study are included in the article/Supplementary Material.

\section{REFERENCES}

Akinyanju, J., and Smith, R. J. (1979). Accumulation of ppGpp and pppGpp during nitrogen deprivation of the cyanophyte Anabaena cylindrica. FEBS Lett. 107, 173-176. doi: 10.1016/0014-5793(79)80489-5

Akinyanju, J., and Smith, R. J. (1987). The accumulation of phosphorylated guanosine nucleotides in Anabaena cylindrica. New Phytol. 105, 117-122. doi: 10.1111/j.1469-8137.1987.tb00115.x

Atkinson, G. C., Tenson, T., and Hauryliuk, V. (2011). The RelA/SpoT homolog (RSH) superfamily: distribution and functional evolution of ppGpp synthetases and hydrolases across the tree of Life. PLoS One 6:e23479. doi: 10.1371/journal. pone.0023479

Baker, N. R. (2008). Chlorophyll fluorescence: a probe of photosynthesis In Vivo. Annu. Rev. Plant Biol. 59, 89-113. doi: 10.1146/annurev.arplant.59.032607. 092759

Beversdorf, L. J., Miller, T. R., and Mcmahon, K. D. (2013). The role of nitrogen fixation in cyanobacterial bloom toxicity in a temperate, eutrophic lake. PLoS One 8:e56103. doi: 10.1371/journal.pone.0056103

Bowler, C., Van Montagu, M., and Inze, D. (1992). Superoxide dismutase and stress tolerance. Annu. Rev. Plant Bio. 43, 83-116.

Braeken, K., Moris, M., Daniels, R., Vanderleyden, J., and Michiels, J. (2006). New horizons for (p)ppGpp in bacterial and plant physiology. Trends Microbiol. 14, 45-54. doi: 10.1016/j.tim.2005.11.006

Chakraburtty, R., and Bibb, M. J. (1997). The ppGpp synthetase gene (RelA) of streptomyces coelicolor A3(2) plays a conditional role in antibiotic and morphological differentiation. J. Bacteriol. 179, 5854-5861. doi: 10.1128/jb.179. 18.5854-5861.1997

\section{AUTHOR CONTRIBUTIONS}

$\mathrm{HJ}, \mathrm{YL}$, and $\mathrm{ZC}$ designed the research and wrote the manuscript. $\mathrm{HJ}$, YL, and KY performed the experiments. HJ, YL, and JZ analyzed the data. All authors contributed to the article and approved the submitted version.

\section{FUNDING}

This work was funded by the S\&T Projects at the Shenzhen Science and Technology Innovation Committee (JCYJ20150831192329178, JCYJ20190808152805472, JSGG20140519113458237, CXZZ20150529165045063, and KQJSCX2016022619041970), the Guangdong Basic and Applied Basic Research Foundation (2019A1515012227), the National Natural Science Foundation of China (32000071), and funding from the China Postdoctoral Science Foundation (2017M620756).

\section{ACKNOWLEDGMENTS}

We are grateful to Professor Cashel for his kind donation of CF1648 and CF1693.

\section{SUPPLEMENTARY MATERIAL}

The Supplementary Material for this article can be found online at: https://www.frontiersin.org/articles/10.3389/fmicb. 2020.511801/full\#supplementary-material

Chia, M. A., Jankowiak, J. G., Kramer, B. J., Goleski, J. A., Huang, I. S., Zimba, P. V., et al. (2018). Succession and toxicity of Microcystis and Anabaena (Dolichospermum) blooms are controlled by nutrient-dependent allelopathic interactions. Harmful Algae 74, 67-77. doi: 10.1016/j.hal.2018.03.002

Conley, D. J., Paerl, H. W., Howarth, R. W., Boesch, D. F., Seitzinger, S. P., Havens, K. E., et al. (2009). Controlling Eutrophication: nitrogen and phosphorus. Science 323, 1014-1015.

Dahl, J. L., Arora, K., Boshoff, H. I., Whiteford, D. C., Pacheco, S. A., Walsh, O. J., et al. (2005). The relA homolog of Mycobacterium smegmatis affects cell appearance, viability, and gene expression. J. Bacteriol. 187, 2439-2447. doi: 10.1128/jb.187.7.2439-2447.2005

Elser, J. J., Bracken, M. E. S., Cleland, E. E., Gruner, D. S., Harpole, W. S., Hillebrand, H., et al. (2007). Global analysis of nitrogen and phosphorus limitation of primary producers in freshwater, marine and terrestrial ecosystems. Ecol. Lett. 10, 1135-1142. doi: 10.1111/j.1461-0248.2007.01 113.x

Eymann, C., Mittenhuber, G., and Hecker, M. (2001). The stringent response, sigmaH-dependent gene expression and sporulation in Bacillus subtilis. Mol. Gen. Genet. 264, 913-923. doi: 10.1007/s004380000381

Findlay, D. L., Hecky, R. E., Hendzel, L. L., Stainton, M. P., and Regehr, G. W. (1994). Relationship Between N2-Fixation and Heterocyst Abundance and its Relevance to the Nitrogen Budget of Lake 227. Can. J. Fish. Aquat. Sci. 51, 2254-2266. doi: 10.1139/f94-229

Friga, G. M., Borbely, G., and Farkas, G. L. (1981). Accumulation of guanosine tetraphosphate (ppGpp) under nitrogen starvation in Anacystis nidulans, a cyanobacterium. Arch. Microbiol. 129, 341-343. doi: 10.1007/bf00 406458 
Frølund, B., Palmgren, R., Keiding, K., and Nielsen, P. H. (1996). Extraction of extracellular polymers from activated sludge using a cation exchange resin. Water Res. 30, 1749-1758. doi: 10.1016/0043-1354(95)00323-1

Gentry, D. R., and Cashel, M. (1996). Mutational analysis of the Escherichia coli spoT gene identifies distinct but overlapping regions involved in ppGpp synthesis and degradation. Mol. Microbiol. 19, 1373-1384. doi: 10.1111/j.13652958.1996.tb02480.x

Harris, B. Z., Kaiser, D., and Singer, M. (1998). The guanosine nucleotide (p)ppGpp initiates development and A-factor production in Myxococcus xanthus. Gene. Dev. 12, 1022-1035. doi: 10.1101/gad.12.7.1022

Havens, K. E. (2008). "Cyanobacteria blooms: effects on aquatic ecosystems," in Cyanobacterial Harmful Algal Blooms: State of the Science and Research Needs, ed. H. K. Hudnell (New York, NY: Springer), 733-747. doi: 10.1007/978-0-38775865-7_33

Hesketh, A., Chen, W. J., Ryding, J., Chang, S., and Bibb, M. J. (2007). The global role of ppGpp synthesis in morphological differentiation and antibiotic production in Streptomyces coelicolor A3(2). Genome Biol. 8, 1-18. doi: 10. 3209/saj.8_1

Hess, W. R., Berghoff, B. A., Wilde, A., Steglich, C., and Klug, G. (2014). Riboregulators and the role of Hfq in photosynthetic bacteria. RNA Biol. 11, 413-426. doi: 10.4161/rna.28035

Higgins, S. N., Paterson, M. J., Hecky, R. E., Schindler, D. W., Venkiteswaran, J. J., and Findlay, D. L. (2018). Biological nitrogen fixation prevents the response of a eutrophic lake to reduced loading of nitrogen: evidence from a 46-year whole-lake experiment. Ecosystems 21, 1088-1100. doi: 10.1007/s10021-0170204-2

Huang, L., McCluskey, M. P., Ni, H., and LaRossa, R. A. (2002). Global gene expression profiles of the Cyanobacterium Synechocystis sp. Strain PCC 6803 in response to irradiation with UV-B and white light. J. Bacteriol. 184, 6845-6858. doi: $10.1128 /$ jb.184.24.6845-6858.2002

Inaoka, T., and Ochi, K. (2002). RelA protein is involved in induction of genetic competence in certain Bacillus subtilis strains by moderating the level of intracellular GTP. J. Bacteriol. 184, 3923-3930. doi: 10.1128/jb.184.14.39233930.2002

Ito, D., Kato, T., Maruta, T., Tamoi, M., Yoshimura, K., and Shigeoka, S. (2012). Enzymatic and molecular characterization of Arabidopsis ppGpp pyrophosphohydrolase, AtNUDX26. Biosci. Biotech. Biochem. 76, 2236-2241. doi: 10.1271/bbb.120523

Jin, H., Lao, Y. M., Zhou, J., Zhang, H. J., and Cai, Z. H. (2018). A rapid UHPLCHILIC method for algal guanosine $5^{\prime}$-diphosphate $3^{\prime}$-diphosphate (ppGpp) and the potential separation mechanism. J. Chromatogr. B 1096, 143-153. doi: 10.1016/j.jchromb.2018.08.009

Klotz, A., Georg, J., Bucinska, L., Watanabe, S., Reimann, V., Januszewski, W., et al. (2016). Awakening of a dormant cyanobacterium from nitrogen chlorosis reveals a genetically determined program. Curr. Bio. 26, 2862-2872. doi: 10. 1016/j.cub.2016.08.054

Klotz, A., Reinhold, E., Doello, S., and Forchhammer, K. (2015). Nitrogen starvation acclimation in Synechococcus elongatus: redox-control and the role of nitrate reduction as an electron sink. Life 5, 888-904. doi: 10.3390/life5010888

Kulasooriya, S. A. (2011). Cyanobacteria: pioneers of planet earth. Ceylon J. Sci. 40, 71-88. doi: 10.4038/cjsbs.v40i2.3925

Laurentin, A., and Edwards, C. A. (2003). A microtiter modification of the anthrone-sulfuric acid colorimetric assay for glucose-based carbohydrates. Anal. Biochem. 315, 143-145. doi: 10.1016/s0003-2697(02)00704-2

Lewis, M. A. (2017). The effectiveness of cyanobacteria nitrogen fixation: review of bench top and pilot scale nitrogen removal studies and implications for nitrogen removal programs. Environ. Rev. 25, 1-4.

Maekawa, M., Honoki, R., Ihara, Y., Sato, R., Oikawa, A., Kanno, Y., et al. (2015). Impact of the plastidial stringent response in plant growth and stress responses. Nat. plants 1, 15167-15173.

Magnusson, L. U., Farewell, A., and Nystrom, T. (2005). ppGpp: a global regulator in Escherichia coli. Trends Microbiol. 13, 236-242. doi: 10.1016/j.tim.2005.03. 008

Masuda, S. (2012). The Stringent Response in Phototrophs. London: InTech, 487500.

Mittler, R. (2002). Oxidative stress, antioxidants and stress tolerance. Trends Plant Sci. 7, 405-410. doi: 10.1016/s1360-1385(02)02312-9

Moisander, P. H., Ochiai, M., and Lincoff, A. (2009). Nutrient limitation of Microcystis aeruginosa in northern California Klamath River reservoirs. Harmful Algae 8, 889-897. doi: 10.1016/j.hal.2009.04.005
Molot, L. A., Watson, S. B., Creed, I. F., Trick, C. G., Mccabe, S. K., Verschoor, M. J., et al. (2014). A novel model for cyanobacteria bloom formation: the critical role of anoxia and ferrous iron. Freshwater Biol. 59, 1323-1340. doi: $10.1111 /$ fwb. 12334

Mulo, P., Sicora, C., and Aro, E. (2009). Cyanobacterial psbA gene family: optimization of oxygenic photosynthesis. Cell Mol. Life Sci. 66, 3697-3710. doi: 10.1007/s00018-009-0103-6

Nanamiya, H., Kasai, K., Nozawa, A., Yun, C., Narisawa, T., Murakami, K., et al. (2008). Identification and functional analysis of novel (p)ppGpp synthetase genes in Bacillus subtilis. Mol. Microbiol. 67, 291-304. doi: 10.1111/j.1365-2958. 2007.06018.x

Nguyen, D., Joshidatar, A., Lepine, F., Bauerle, E., Olakanmi, O., Beer, K., et al. (2011). Active starvation responses mediate antibiotic tolerance in biofilms and nutrient-limited bacteria. Science 334, 982-986. doi: 10.1126/science.1211037

Owusu-Ansah, E., Yavari, A., and Banerjee, U. (2008). A protocol for in vivo detection of reactive oxygen species. Prot. Exchange doi: 10.1038/nprot.2008.23

Paerl, H. W., Fulton, R. S., Moisander, P. H., and Dyble, J. (2001). Harmful freshwater algal blooms, with an emphasis on cyanobacteria. Sci. World J. 1, 76-113. doi: 10.1100/tsw.2001.16

Paerl, H. W., and Otten, T. G. (2016). Duelling 'CyanoHABs': unravelling the environmental drivers controlling dominance and succession among diazotrophic and non-NR2R-fixing harmful cyanobacteria. Environ. Microbiol. 18, 316-324. doi: 10.1111/1462-2920.13035

Paerl, H. W., and Tucker, C. S. (1995). Ecology of blue-green algae in aquaculture ponds. J. World Aquacul. Soc. 26, 109-131. doi: 10.1111/j.1749-7345.1995. tb00235.x

Paerl, H. W., Xu, H., Mccarthy, M. J., Zhu, G., Qin, B., Li, Y., et al. (2011). Controlling harmful cyanobacterial blooms in a hyper-eutrophic lake (Lake Taihu, China): the need for a dual nutrient (N \& P) management strategy. Water Res. 45, 1973-1983. doi: 10.1016/j.watres.2010.09.018

Pérez, C. A., Silva, W. A., Aravena, J. C., and Armesto, J. J. (2017). Limitations and relevance of biological nitrogen fixation during postglacial succession in cordillera darwin, Tierra del Fuego, Chile. Arctic Antarctic Alpine Res. 49, 29-42. doi: 10.1657/aaar0016-014

Polle, A. (2001). Dissecting the superoxide dismutase-ascorbate-glutathionepathway in chloroplasts by metabolic modeling, Computer Simulations as a Step towards Flux Analysis. Plant Physiol. 126, 445-462. doi: 10.1104/pp.126.1. 445

Potrykus, K., Murphy, H., Philippe, N., and Cashel, M. (2011). ppGpp is the major source of growth rate control in E. coli. Environ. Microbiol. 13, 563-575. doi: 10.1111/j.1462-2920.2010.02357.x

Rifat, D., Bishai, W. R., and Karakousis, P. C. (2009). Phosphate depletion: a novel trigger for Mycobacterium tuberculosis Persistence. J. Infec. Dis. 200, $1126-1135$.

Sauer, J., Schreiber, U., Schmid, R., Volker, U., and Forchhammer, K. (2001). Nitrogen Starvation-Induced Chlorosis in Synechococcus PCC 7942, low-level photosynthesis as a mechanism of long-term survival. Plant Physiol. 126, 233-243. doi: 10.1104/pp.126.1.233

Schindler, D. W., Hecky, R. E., Findlay, D. L., Stainton, M. P., Parker, B. R., Paterson, M. J., et al. (2008). Eutrophication of lakes cannot be controlled by reducing nitrogen input: results of a 37-year whole-ecosystem experiment. Proc. Natl. Acad. Sci. U.S.A. 105, 11254-11258. doi: 10.1073/pnas.08051 08105

Sheng, G., Yu, H., and Li, X. (2010). Extracellular polymeric substances (EPS) of microbial aggregates in biological wastewater treatment systems: a review. Biotech. Adv. 28, 882-894. doi: 10.1016/j.biotechadv.2010.08.001

Smith, R. J., and Carr, N. G. (1977). The Regulation of Stable RNA Synthesis in the Blue-green Alga Anacystis nidulans: effect of Leucine Deprivation and 5-Methyltryptophan Inhibition. Microbiology 103, 61-68. doi: 10.1099/ 00221287-103-1-61

Smith, V. H. (1983). Low nitrogen to phosphorus ratios favor dominance by bluegreen algae in lake phytoplankton. Science 221, 669-671. doi: 10.1126/science. 221.4611.669

Smith, V. H. (1990). Nitrogen, phosphorus, and nitrogen fixation in lacustrine and estuarine ecosystems. Limnol. Oceanogr. 35, 1852-1859. doi: 10.4319/lo.1990. 35.8.1852

Struck, U., Pollehne, F., Bauerfeind, E., and Von Bodungen, B. (2004). Sources of nitrogen for the vertical particle flux in the Gotland Sea (Baltic Proper)-results from sediment trap studies. J. Mar. Syst. 45, 91-101. doi: 10.1016/j.jmarsys. 2003.11.012 
Szlag, D. C., Sinclair, J., Southwell, B., and Westrick, J. (2015). Cyanobacteria and cyanotoxins occurrence and removal from five high-risk conventional treatment drinking water plants. Toxins 7, 2198-2220. doi: 10.3390/ toxins 7062198

Takahashi, K., Kasai, K., and Ochi, K. (2004). Identification of the bacterial alarmone guanosine $5^{\prime}$-diphosphate $3^{\prime}$-diphosphate (ppGpp) in plants. Proc. Natl. Acad. Sci. U.S.A. 101, 4320-4324. doi: 10.1073/pnas.0308555101

Thomas, R. H., and Walsby, A. E. (1985). Buoyancy regulation in a strain of Microcystis. Microbiology 131, 799-809. doi: 10.1099/00221287-131-4-799

Traxler, M. F., Chang, D.-E., and Conway, T. (2006). Guanosine 3', 5'bispyrophosphate coordinates global gene expression during glucose-lactose diauxie in Escherichia coli. Proc. Natl. Acad. Sci. U.S.A. 103, 2374-2379. doi: 10.1073/pnas.0510995103

Traxler, M. F., Summers, S. M., Nguyen, H., Zacharia, V. M., Hightower, G. A., Smith, J. T., et al. (2008). The global, ppGpp-mediated stringent response to amino acid starvation in Escherichia coli. Mol. Microbiol. 68, 1128-1148. doi: 10.1111/j.1365-2958.2008.06229.x

Traxler, M. F., Zacharia, V. M., Marquardt, S., Summers, S. M., Nguyen, H., Stark, S. E., et al. (2011). Discretely calibrated regulatory loops controlled by ppGpp partition gene induction across the 'feast to famine' gradient in Escherichia coli. Mol. Microbiol. 79, 830-845. doi: 10.1111/j.1365-2958.2010.07498.x

Van Delden, C., Comte, R., and Bally, A. M. (2001). Stringent response activates quorum sensing and modulates cell density-dependent gene expression in Pseudomonas aeruginosa. J. Bacteriol. 183, 5376-5384. doi: 10.1128/jb.183.18. 5376-5384.2001

van der Biezen, E. A., Sun, J., Coleman, M. J., Bibb, M. J., and Jones, J. D. (2000). Arabidopsis RelA/SpoT homologs implicate (p) ppGpp in plant signaling. Proc. Natl. Acad. Sci. U.S.A. 97, 3747-3752. doi: 10.1073/pnas.97.7.3747

Vinella, D., Albrecht, C., Cashel, M., and D’Ari, R. (2005). Iron limitation induces SpoT-dependent accumulation of ppGpp in Escherichia coli. Mol. Microbiol. 56:958. doi: 10.1111/j.1365-2958.2005.04601.x

Wendrich, T. M., Blaha, G., Wilson, D. N., Marahiel, M. A., and Nierhaus, K. H. (2002). Dissection of the Mechanism for the Stringent Factor RelA. Mol. Cell 10, 779-788. doi: 10.1016/s1097-2765(02)00656-1

Wood, N. B., and Haselkorn, R. (1980). Control of phycobiliprotein proteolysis and heterocyst differentiation in Anabaena. J. Bacteriol. 141, 1375-1385. doi: $10.1128 /$ jb.141.3.1375-1385.1980
Xiao, H., Kalman, M., Ikehara, K., Zemel, S., Glaser, G., and Cashel, M. (1991). Residual guanosine $3^{\prime}, 5^{\prime}$-bispyrophosphate synthetic activity of RelA null mutants can be eliminated by SpoT null mutations. J. Biol. Chem. 266, 59805990.

Xu, H., Jiang, H., Yu, G., and Yang, L. (2014). Towards understanding the role of extracellular polymeric substances in cyanobacterial Microcystis aggregation and mucilaginous bloom formation. Chemosphere 117, 815-822. doi: 10.1016/ j.chemosphere.2014.10.061

Yang, X., and Ishiguro, E. E. (2003). Temperature-sensitive growth and decreased thermotolerance associated with relA mutations in Escherichia coli. J. Bacteriol. 185, 5765-5771. doi: 10.1128/jb.185.19.5765-5771.2003

Yang, Z., Kong, F., and Shi, X. (2005). Effects of filtered lake water on colony formation and growth rate in microcystis aeruginosa of different physiological phases. J. Freshwater Ecol. 20, 425-429.

Yang, Z., Zhang, M., Shi, X., Kong, F., Ma, R., and Yu, Y. (2016). Nutrient reduction magnifies the impact of extreme weather on cyanobacterial bloom formation in large shallow Lake Taihu (China). Water Res. 103, 302-310.

Zhang, S., Lin, G., Chen, W., Wang, L., and Zhang, C. (2013). ppGpp Metabolism Is Involved in Heterocyst Development in the Cyanobacterium Anabaena sp. Strain PCC 7120. J. Bacteriol. 195, 4536-4544.

Zhu, J. (2016). Abiotic stress signaling and responses in plants. Cell 167, 313-324.

Zou, W., Wang, Z., Song, Q., Tang, S., and Peng, Y. (2018). Recruitment-promoting of dormant Microcystis aeruginosa by three benthic bacterial species. Harmful Algae 77, 18-28.

Conflict of Interest: The authors declare that the research was conducted in the absence of any commercial or financial relationships that could be construed as a potential conflict of interest.

Copyright (c) $2020 \mathrm{Jin}$, Lao, Ying, Zhou and Cai. This is an open-access article distributed under the terms of the Creative Commons Attribution License (CC BY). The use, distribution or reproduction in other forums is permitted, provided the original author(s) and the copyright owner(s) are credited and that the original publication in this journal is cited, in accordance with accepted academic practice. No use, distribution or reproduction is permitted which does not comply with these terms. 